\title{
MANAJEMEN KOMPETENSI SUMBER DAYA MANUSIA BANK SYARIAH BERBASIS PRINSIP-PRINSIP SYARIAH MENUJU QUALIFIED ASEAN BANK
}

\author{
Suad Fikriawan \\ Dosen Program Studi Hukum Ekonomi Syariah \\ Fakultas Syariah IAI Sunan Giri Ponorogo \\ suadfikriawan@gmail.com
}

\begin{abstract}
Keywords:
Competency Management,

Human Resources Sharia

Banks, Qualified Asean

Bank
\end{abstract}

\author{
Kata Kunci: \\ Manajemen \\ Kompetensi, SDM \\ Bank Syarah, Qualified \\ Asean Bank.
}

\begin{abstract}
The aim of this research is to design the initial idea in the management of competence of Human Resources Bank Syariab toward the qualified asean bank. As an initial anxiety researchers are how the problem of stagnation of assets and capital of Islamic banks in the last few decades is one of them due to the low competence of human resources Islamic banks. Besides other problems is the availability of qualified human resources in the field kesyariahan very less when compared to the growth rate of sharia bank office in Indonesia. Therefore, the focus of this study is to examine how the management of human resources competence of sharia banks in accordance with the principles of sharia. Which then how the functionalization of sharia principles in the design of competency management of Islamic banks in particular able to achieve target qualified asean banks. The results of this study describes a bypothesis that the theory developed by sharia banks is relevant when using the concept of personal competency and organizational competency initiated by Spencer and John W. Slocum. But in the contestation of its functionalization should be based on the values of sharia which is presented in his theory Irawan Amin is Mananjemen Langit which includes three basic principles of Worship, Wealth, and Warfare.
\end{abstract}

\section{ABSTRAK}

Tujuan dari penelitian ini adalah untuk merancang gagasan awal dalam manajemen kompetensi Sumber Daya Manusia Bank Syariah menuju qualified asean bank. Sebagai kegelisahan awal peneliti adalah bagaimana problem stagnasi asset dan permodalan bank syariah pada beberapa dekade terakhir ini terjadi salah satunya akibat kompetensi SDM bank syariah yang rendah. Disamping problem lainnya adalah ketersediaan SDM yang mumpuni di bidang kesyariahan sangat kurang bila dibandingkan tingkat bertumbuhan kantor bank syariah di Indonesia. Oleh karena itu focus penelitian ini mengkaji bagaimana manjemen kompetensi SDM bank syariah yang idela sesuai prinsip-prinsip syariah. Yang kemudian bagaimana fungsionalisasi prinsip syariah dalam desain manajemen kompetensi SDM bank syariah khususnya mampu mencapai target qualified asean bank. Hasil penelitian ini menguraikan suatu hipotesis bahwa teori yang dikembangkan oleh bank syariah relevan bila menggunakan konsep personal competency dan organizational competency yang digagas oleh Spencer dan John W. Slocum. Namun dalam kontes fungsionalisasinya harus berlandaskan pada nilai-nilai syariah yang dikemukakan dalam teorinya Irawan Amin yaitu Mananjemen Langit yang mencakup tiga prinsip dasar yaitu Worship, Wealth, dan Warfare. 
Suad Fikriawan. Manajemen Kompetensi Sumber Daya Manusia Bank Syariah ...

\section{PENDAHULUAN}

Lahirnya sistem syariah dilatarbelakangi oleh semakin berkembangnya masyarakat muslim di Indonesia yang diiringi dengan kesadaran mereka terhadap ketidakadilan skema perbankan konvensional. Alasan lain diungkapkan oleh Setiawan (2006), bahwa pergeseran sistem konvensional ini disebabkan oleh keinginan perubahan terhadap sistem sosial politik dan ekonomi yang berlandaskan prinsip-prinsip Islam dan kepribadian Islam yang lebih kuat, sekaligus sebagai upaya reformasi makro ekonomi dan reformasi struktural dalam sistem negara-negara muslim. Mereka menginginkan keluar dari jeratan pengaruh sistem kapitalisme. Tantangan untuk mewujudkan sistem yang syariah ternyata tidak semudah yang diucapkan para pelopornya. Terbukti pada tahun 1958 salahseorang ekonom terkemuka Indonesia, Muhammad Hatta justru dengan tegas menolak gagasan untuk mendirikan Bank Islam yang bebas bunga, karena menurutnya bank tidak akan langgeng tanpa menerapkan bunga (Muhammad, 2005).

Proses pergolakan politik dan kebijakan itu bergulir sampai akhir era orde baru dimana saat kepemimpinan Soeharto tahun 1992 dilakukan revisi atas undang-undang perbankan yang mengakui dan melegalkan sistem perbankan Islami. Hingga lahirlah Bank Muamalah sebagai pelopor bank Syariah di Indonesia. Meskipun tergolong terlambat dalam melahirkan sistem syariah, namun fenomena ini tidak menyurutkan semangat para muslim untuk tetap gencar menyuburkan praktik pebankan syariah di Indonesia. Dapat dilihat dalam Bi outlook sejak tahun 1998-2012 (14 tahun) perkembangan bank syariah cukup signifikan hingga mencapai angka pertumbuhan 45\%-78\% per tahun (BI, Statistik Perbankan Indonesia, 2012)

Namun dalam cetak biru pengembangan perbankan syariah saat ini, dimana perbankan syariah nasional berada pada fase keempat (2013-2015), antara perkembangan jaringan usaha syariah (kantor perbankan) dengan perkembangan aset menunjukkan hasil yang tidak sesuai dengan target yang diinginkan. Dalam statistik perbankan Indonesia per Desember 2014 terdapat tidak kurang 12 Bank Umum Syariah dan 22 Unit Usaha Syariah dari suatu bank konvensional dengan total keseluruhan jaringan kantor 2.151 unit. Selain itu, Total aset bank umum syariah mencapai 272.343 (dalam miliar rupiah). Jumlah ini masih relatif kecil jika dibandingkan dengan total aset perbankan nasional secara umum yang mencapai 5.615.150 (dalam miliar rupiah). Artinya pangsa pasar perbankan syariah masih sangat kecil hanya 4,85\%, padahal target pangsa pasar perbankan syariah adalah sebesar 15\% pada akhir tahun 2015 . Hal ini tentunya mendorong bagi praktisi perbankan syariah agar sesegera mungkin mencari strategi pengembangan perbankan syariah secara lebih massif.

Menurut Direktur Perbankan Syariah OJK Dhani Gunawan Idhat dalam harian Tempo (2016), menyatakan setidaknya ada 7 masalah yang saat ini dihadapi Bank Syariah, Diantaranya problem SDM yang berkualitas. Peran Sumber Daya Manusia (SDM) yang berkualitas dalam upaya memajukan perbankan syariah adalah yang utama. Asset berwujud yang dimiliki entitas seperti bangunan, peralatan, mesin produksi, akan menjadi modal yang tidak memberikan kontribusi maksimal jika tidak didukung dengan kualitas SDM. Seperti yang diungkapkan oleh Ulrich yang dikutip oleh Nurhayati (2009), bahwa knowledge yang ada pada manusia merupakan salah satu item yang digunakan untuk meningkatkan daya saing baik dalam menjual ide (selling idea). Telah banyak contoh Negara yang berhasil bangkit karena kebangkitan kualitas SDM mereka. Ambil contoh China yang pada akhirnya mampu menjadi Negara raksasa karena keberhasilannya dalam memperbaiki kualitas masyarakat akademisi dengan mendorong mereka belajar ke Negara lain di dunia. Dengan kata lain, kemajuan suatu peradaban ditentukan oleh faktor kualitas masyarakatnya.

Tema tentang SDM ini pulalah yang sepertinya menjadi salah satu alasan utama mengapa syariah belum bisa berkembang secara maksimal di Indonesia (Sulistiyo, 2010). Sumber daya manusia Bank Syariah harus lebih kreatif dan inovatif dalam mengembangan dan memodifikasi produk-produk perbankan. Sumber daya Bank Syariah harus meningkatkan 
kompetensi dan keahlian dalam bidang perbankan dan keuangan syariah, disamping juga harus memahami tentang kontrak-kontrak syariah, sehingga dapat memodifikasi produk yang memenuhi prinsip-prinsip syariah.

Sumber daya bank syariah harus bisa memberikan pelayanan dan kepercayaan kepada masyarakat tentang produk perbankan syariah yang sesuai dengan etika dan prinsip Islam. Dalam hal ini juga penting bagi SDM bank syariah untuk meningkatkan kompetensi dalam hal investasi keuangan dan perbankan, soft skill, dan ke-syariah-an. Akan tetapi kondisi ini langka di perbankan syariah. Permasalahan ini ada karena terbatasnya aspek lembaga pendidkan dan pelatihan dalam bidang perbankan syariah. Faktanya terlihat pada hampir semua sumber daya perbankan syariah khususnya pada jajaran manajemen tingkatan menengah dan atas yang didapatkan dari bank konvensional. Hal itu diperdiksikan dari hampir 70\% karyawan bank syariah hari ini berasal dari bank konvensional atau bukan dari pendidikan yang berbasis Ekonomi Syariah. Maka, pemenuhan sumber daya manusia perbankan syariah secara sempurna menjadi suatu keharusan, baik dari aspek kualitatif maupun kuantitatif (Laporan Tahunan Bank Indonesia, 2012 : 6).

Minimnya pemahaman tentang mekanisme transaksi keuangan syariah dan lebih lagi dipupuk dengan rasa acuh untuk berusaha memahami mekanisme syariah, pada akhirnya akan menghasilkan sebuah simpulan masyarakat bahwa ternyata praktik perbankan syariah tidak berbeda dengan konvensional. Dapat kita bayangkan jika ketiga pihak yang memegang peranan penting dalam perkembangan syariah kurang memahami hakikat syariah serta akad transaksi syariah yang mengikutinya, maka dapat dipastikan perbankan syariah di negeri ini tidak akan mampu berkembang pesat untuk bersaing dengan Negara muslim lainnya.

Dalam Muhammad (2005), dinyatakan bahwa kredibilitas dan profesionalitas institusi keuangan dapat dibangun berlandaskan tiga elemen, yaitu humanware, hardware, dan software. Humanware adalah seseorang yang mengatur lembaga mulai dari tingkat atas dampai tingkat bawah. Humanware harus sesuai antara aspek kualitas dan kuntitas. Sedangkan hardware termasuk alat produksi dan perlengkapan fisik seperti mesin, gedung, dan lainnya. Sedangkan software termasuk beberapa hal yang bukan fisik, misalnya prosedur, sistem, dan lainnya. Adapun tantangan yang dihadapi dalam waktu dekat ini adalah diberlakukannya era pasar bebas Asean (MEA). Di sektor perbankan, Bank Indonesia dan Otoritas Jasa Keuangan (OJK) memberikan persetujuan terhadap ASEAN Banking Integration Framework (ABIF) Guidelines, yang menjadi panduan rerangka operasional bagi negara-negara ASEAN dalam mengimplementasikan prinsip-prinsip dan proses integrasi perbankan di bawah rerangka Masyarakat Ekonomi ASEAN. Dalam kesepakatan itu pula, Bank Indonesia (BI) ditunjuk sebagai co-chair Task Force on ASEAN Banking Integration Framework (TF ABIF) bersama dengan Bank Negara Malaysia.

Tugas utama TF ABIF adalah menyusun kerangka kerja dan pedoman pelaksanaan integrasi perbankan dalam konteks ABIF yang bertujuan untuk meningkatkan kehadiran dan peran bank-bank terbaik asli (indigenous bank) ASEAN di negara-negara ASEAN. Tujuan utama ABIF adalah menyediakan akses pasar (market access) dan keleluasaan beroperasi (operational flexibility) di negara anggota ASEAN bagi Qualified ASEAN Banks (QAB), yakni bank-bank ASEAN dengan persyaratan tertentu yang telah disepakati bersama oleh ASEAN. Persyaratan bank untuk menjadi kandidat QAB antara lain bank-bank milik ASEAN yang kuat permodalannya, berdaya tahan tinggi, dikelola dengan baik, serta memenuhi ketentuan kehati-hatian sesuai standar internasional yang berlaku. Bank-bank tersebut diharapkan akan menjadi pendorong perdagangan dan investasi di ASEAN.

Dalam penilaian Global Islamic Financial Report (GIFR) tahun 2015, Indonesia menduduki urutan ke-7 dari 45 negara yang memiliki potensi dan kondusif dalam pengembangan industri keuangan syariah setelah Iran, Malaysia dan Saudi Arabia, UEA, Kuwait, dan Bahrain. 
Suad Fikriawan. Manajemen Kompetensi Sumber Daya Manusia Bank Syariah ...

Dengan melihat beberapa aspek dalam penghitungan indeks, seperti jumlah bank syariah, jumlah lembaga keuangan non bank syariah, maupun ukuran aset keuangan syariah yang memiliki bobot terbesar, maka Indonesia diproyeksikan akan menduduki peringkat pertama dalam beberapa tahun ke depan. Maka optimisme tersebut harus didukung dengan Sumber Daya Manusia Bank Syariah yang unggul dan kompeten.

Secara umum daya saing dan kompetensi Sumber daya manusia Indonesia di tingkat Asean dapat dilihat pada tabel HDI Index tahun 2014 berikut ini:

Table 1: Human Development Index and its components 2015

\begin{tabular}{llccccccc}
\hline Rank & Country & $\begin{array}{c}\text { World } \\
\text { Rank }\end{array}$ & HDI & $\begin{array}{c}\text { Life } \\
\text { Ecpect } \\
\text { ancy at } \\
\text { Birth }\end{array}$ & $\begin{array}{c}\text { Expected } \\
\text { years of } \\
\text { Scholling }\end{array}$ & $\begin{array}{c}\text { Mean } \\
\text { years of } \\
\text { Schooling }\end{array}$ & $\begin{array}{c}\text { GNI } \\
\text { per } \\
\text { Capita }\end{array}$ & $\begin{array}{c}\text { GNI } \\
\text { Ra - } \\
\text { Rank }\end{array}$ \\
\hline 1 & Singapore & 11 & 0.911 & 83.0 & 15.4 & 10.6 & 76,628 & -7 \\
2 & Brunei D & 31 & 0.855 & 78.8 & 14.5 & 8.8 & 72,570 & -26 \\
3 & Malaysia & 62 & 0.779 & 74.7 & 12.7 & 10.0 & 22,762 & -14 \\
4 & Thailand & 93 & 0.725 & 74.4 & 13.5 & 7.3 & 13,323 & -13 \\
5 & Indonesia & 110 & 0.683 & 68.9 & 13.0 & 7.6 & 9,788 & -9 \\
6 & Phillipines & 115 & 0.668 & 68.2 & 11.3 & 8.9 & 7,915 & -7 \\
7 & Myanmar & 148 & 0.535 & 65.9 & 8.6 & 4.1 & 4,608 & -12 \\
\hline
\end{tabular}

Sumber: http://hdr.undp.org/en/composite/HDI, Tahun 2016

Dalam tabel diatas dijelaskan bahwa Indonesia menduduki peringkat kelima dari tujuh Negara di Asia Tenggara (peringkat 110 dari 188 negara di dunia). Rata-rata indeks Pembangunan Manusianya (dengan indikator Umur, Kesehatan, Pengetahuan, dan standar hidup layak) sebesar 68,3\% pada tahun 2015. Artinya jika diasumsikan jumlah penduduk Indonesia 220 juta jiwa maka tingkat kelayakan hidup diatas standar sejumlah 105,26 juta jiwa. Sedangkan 49,74 juta jiwa masih dibawah standar hidup, kesehatan, dan pendidikan yang layak.

Kembali pada penelitian yang dilakukan oleh Munthe,tentang pemetaan supply dan demand kebutuhan sumber daya manusia bank syariah. Hasil penelitian ini menunjukkan bahwa kebutuhan sumber daya manusia untuk akselerasi bank syariah berjumlah 179.646 orang pegawai dari 37.356 orang pada akhir tahun 2012. Jumlah tersebut akan terdiri dari 165.274 orang pegawai kategori low Syariah quality, dan 14.372 orang kategori middle to high syariah quality. Supply gap SDM syariah kategori low syariah quality akan terjadi sampai dengan tahun 2016 dan kategori middle to high syariah quality, hingga tahun 2020 (Azmy, 2015; 78-90).

Pada Tabel Statistik Perbankan Syariah tahun 2013 menunjukkan bahwa dengan pertumbuhan bank syariah menuntut adanya peningkatan jumlah tenaga kerja di bank syariah. Pada tahun 2013 jumlah bank umum syariah berjumlah 26.717 orang, kemudian unit usaha syariah berjumlah 11.223 orang, dan bank pembiayaan rakyat syariah berjumlah 4.824 orang.

Menurut Rukiah (2015), aspek SDM yang harus ditingkatkan khususnya dalam menyongsong pasar bebas ASEAN, perbankan syariah perlu merumuskan program strategis yang diantaranya mendukung berdirinya lembaga pendidikan yang terkonsentrasi pada Lembaga Keuangan Syariah, mengoptimalkan munculnya peraturan-peraturan dan Regulasi mengenai SDM bank Syariah, Intensifikasi kegiatan pelatihan mengenai sistem Ekonomi Syariah, peningkatan kualitas pengawas dan sistem pengawas dan praktek lembaga keuangan syariah, dan Pembuatan Sertifikasi oleh BNSP kepada tenaga kerja yang profesional. Jika diawali dengan pengembangan kompetensi individual SDM Bank Syariah, maka secara konseptual dapat digambarkan dalam bagan berikut: 


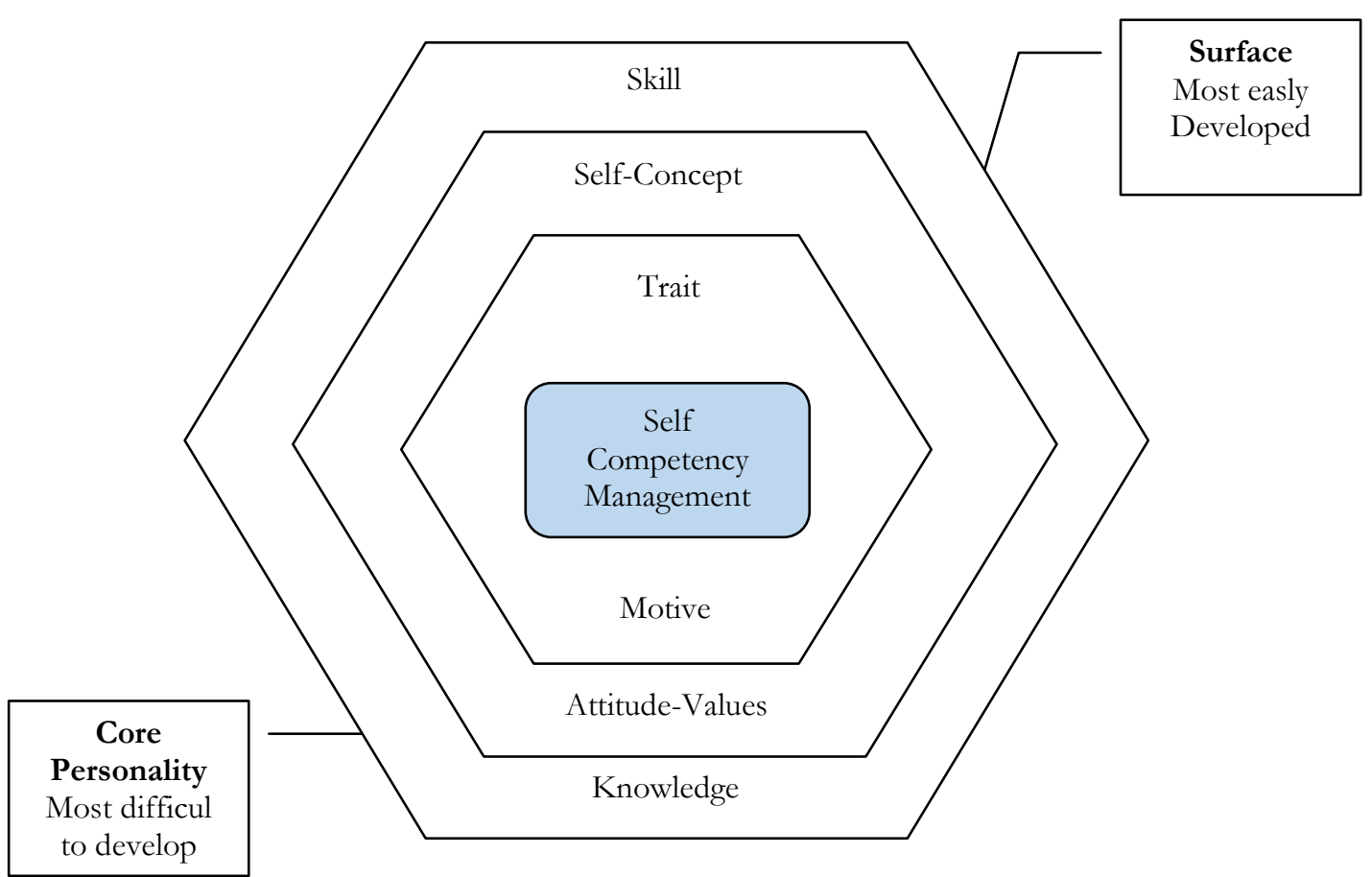

Gambar : R. Palan, Competency Management a Practitioner's Guide 2003.

Konsep yang dikemukakan oleh Spencer dalam R. Palan diatas menjelaskan lingkup pengembangan kompetensi SDM Bank Syariah secara individual yang mencakup pengetahuan dan keterampilan, sikap dan nilai diri serta konsep diri, dan yang paling inti adalah sifat dan motivasi, yang kemudian dalam penelitian ini bagaimana unsur-unsur dalam kompetensi SDM Bank Syariah tersebut dikembangkan secara sistematis melalui sistem organisasi dan manajerial perusahaan yang baik yang berpijak pada nilai-nilai syariah. Kemudian bagaimana implementasi tersebut berimplikasi pada perwujudan cita-cita standarisasi Qualified Islamic Bank (QAB) bagi perbankan Syariah di Indonesia dari aspek pengembangan Sumber Daya Manusia, dan secara terperinci masalah dalam penelitian ini dirumuskan dalam beberapa rumusan masalah berikut. 1). Mengapa Problem kompetensi SDM bank Syariah muncul di tengah perlambatan pertumbuhan Bank Syariah di Indonesia?, 2) Bagaimana Desain pengembangan kompetensi individual dan organisasional pada Perbankan Syariah di Indonesia?, 3). Bagaimana Prinsip-prinsip Syariah berfungsi dalam Proses Manajemen Kompetensi SDM Bank Syariah di Indonesia?.

\section{PEMBAHASAN}

\section{a. Kompetensi SDM Bank Syariah}

Sebelum mengulas banyak hal tentang Kompetensi SDM Bank Syariah terlebih dahulu penulis menjelaskan pengertian kompetensi menurut R. Palan dalam bukunya Competency Management 2003 adalab: 'Kompetensi adalah mengenai orang seperti apa dan apa yang dapat mereka lakukan, bukan apa yang mungkin mereka lakukan“. Sedangkan menurut Mitrani et.all dan Spencer yang dikutip oleh Surya Dharma (2007) mendefinisikan kompetensi sebagai: "Karakterisitik yang mendasari seseorang dan berkaitan dengan efektivitas kinerja individu dalam pekerjaannya (an underlying characteristic's of an individual which is causally related to criterionreferenced effective and or superior performance in a job or situation)". Berdasarkan definisi tersebut bahwa "kata underlying characteristics mengandung makna kompetensi yang merupakan bagian kepribadian yang mendalam dan melekat kepada seseorang, serta perilaku 
Suad Fikriawan. Manajemen Kompetensi Sumber Daya Manusia Bank Syariah ...

yang dapat diprediksi pada berbagai keadaan dan tugas pekerjaan. Kata caussally related berarti kompetensi adalah sesuatu yang menyebabkan atau memprediksi perilaku dan kinerja. Sedangkan kata Criterion-referenced mengandung makna bahwa kompetensi sebenarnya memprediksi siapa yang berkinerja baik dan kurang baik, diukur dari kriteria atau standar yang digunakan".

Dalam konteks SDM Bank Syariah, perkembangan dan pertumbuhannya banyak memberikan warna pada kemampuan dan kompetensi yang dimiliki para bankirnya. namun ketersediaan bankir yang kompeten pada sisi ketrerampilan bidang perbankan dan sisi kesyaraiahannya secara sekaligus jarang ditemui dalam praktik perbankan syariah. Menurut syrvey yang dilakukan peneliti di dua perbankan di dua kota tempat peneliti berdomisili, ratarata para Bankir tersebut hanya mengetahui sebatas beberapa produk perbankan syariah yang menjadi bagian dari kerja mereka sehari-hari. Mereka lebih mengutamakan aspek profesionalitas kerja secara umum yang meliputi sikap kerja, motivasi, dan focus pada targettarget perbankan saja. Persoalan syariah atau yang lain bukan menjadi tugas dan wewenang mereka untuk mengetahuinya.

Padahal salah satu faktor yang menentukan peningkatan kinerja lembaga bank adalah dengan ketersediaan SDM dan infrastruktur pendukung yang berkualitas. SDM yang berkualitas yang dibutuhkan oleh bank syariah adalah SDM yang secara keilmuan paham tentang konsep bank syariah dan ekonomi syariah, dan secara psikologis dia memiliki semangat keislaman yang tinggi. SDM yang hanya mengerti tentang ilmu bank syariah dan ekonomi syariah saja, tetapi tidak memiliki semangat keislaman yang tinggi, maka ilmunya bagai tidak ada ruh. Sehingga dalam beraktifitas sehari-hari dia tidak ada rasa memiliki (sense of belonging) dan rasa tanggung jawab (sense of responsibility)terhadap kemajuan bank syariah.

Statemen diatas dikuatkan oleh teori yang dikembangkan oleh Spencer bahwa meningkatkan aspek pengetahuan dalam bekerja merupakan suatu yang penting tetapi mudah untuk dilakukan, tetapi yang paling penting membangun nilai diri dan motivasi yang sesuai dengan pronsip-prinsip agama yang dipercayai sangatlah sulit diwujudkan. Namun ketika nilai diri dan motivasi keagamaan itu dapat diwujudka, n maka visi-dan misi perbankan syariah akan mudah tercapai. Selama ini bank syariah yang ada dan berkembang hanya mampu mencapai visi material dan finansial saja namun secara substansial bank syariah belum mampu mencapai visi utamanya yaitu meningkatkan kemakmuran sektor UMKM di Indonesia.

Problem itu muncul karena pertama bank syariah berkembang belum berbasis pada nilai-nilai islami yang terkandung dalam sistem profit and loss sharing-nya namun hanya profit sharing semata, kedua dengan profit sharing tentu bank syariah dinyatakan belum siap dengan kerugian-kerugian yang ditanggung jika menerapkan prinsip yang sebenarnya. Ketiga investasi sektor perbankan syariah tidak sepadan dengan bank konvensional di Indonesia sehingga perlambatan pertumbuhan asset bank syariah terjadi pada decade terakhir ini. Keempat kompetensi dan profesionalitas SDM nya tidak sebaik SDM bank Konvensional meskipun bank konvensional tidak berbasis prinsi-prinsip Islam.

Maka upaya mempersiapkan kualifikasi Sumber daya Manusia perbankan syari'ah di masa depan, terutama diarahkan kepada upaya peningkatan profesionalisme yang tidak hanya berkaitan dengan masalah keahlian dan ketrampilan saja, namun yang jauh lebih penting adalah menyangkut komitmen moral dan etika bisnis yang mendalam atas profesi yang dijalaninya. Pemahaman dan perwujudan tidak nyata dari nilai-nilai moral agamis merupakan persyaratan mutlak bagi pelaku perbankan syari'ah masa depan.Dengan memahami simpulsimpul permasalahan yang terjadi dan kebijakan-kebijakan yang telah dilakukan, dalam rangka mewujudkan kualitas Sumber daya manusia perbankan syari'ah, perlu difokuskan pada upayaupaya yang mengarah pada peningkatan pemahaman aspek-aspek yang terkait, seperti pemegang saham serta pengelola/pengurus perbankan syari'ah. 
Dalam rangka mengatasi kendala-kendala tersebut, maka diperlukan sebuah upaya yang serius dalam rangka pengenbangan bank syari'ah ke depan, Pertama,penigkatan kualitas sumber daya manusia di bidang perbankan syari'ah. Salah satunya perlu mengembangkan sistem pendidikan yang mnegintegrasikan teori dan praktik perbankan syari'ah dalam rangka meningkatkan integritas bank syari'ah di tengah-tengah masyarakat. Kedua,perlunya upayaupaya yang lebih progresif dari semua pihak yang concern terhadap keberadaan dan pengembangan bank syari'ah baik dari kalangan pemerintah, ulama, praktisi perbankan terutama kalangan akademisi. Ketiga,memberikan kesempatan seluas-luasnya kepada bank konvensional untuk membuka kantor cabang syariah, yang mampu secara legalitas maupun materi, untuk mendirikan bank umum syari'ah di seluruh pelosok negeri.

\section{b. Desain Pengembangan Kompetensi Pada Perbankan Syariah Di Indonesia}

Secara umum Dalam mengungkap kinerja organisasi Nickson (2007:169) mengutip pendapat Armstrong mengenai yaitu : "Performance management is about getting better results from the organization, teams and individuals by understanding and managing performance within an agreed framework of planned goals, standards and competing requirements. It is a process for establishing shared understanding about what is to be achieved, and an approach to managing and developing people in a way which increases the probability that it will be achieved in the short and long term. It is owned and driven by management. "

Berdasarkan pendapatnya di atas dapat dikatakan bahwa kinerja organisasi diperoleh dari pengelolaan berbagai tujuan, sasaran dan pengembangan sumber daya manusia yang ada di dalamnya untuk mencapai tujuan baik jangka pendek maupun jangka panjang. Peran pimpinan dalam hal ini sangat dominan. Sejauh mana pimpinan menghendaki SDM organisasinya berkembang maka pimpinan tersebut memiliki kewenangan dalam mewujudkan pengembangan SDM melalui berbagai kegiatan pengembangan dan pelatihan sesuai dengan masing-masing kompetensi yang dimiliki pegawainya. diantaranya:

Berbagai upaya pengembangan SDM hendaknya didukung oleh beberapa faktor

1. Terdapat seleksi SDM yang baik untuk benar-benar menciptakan pegawai yang berkualitas

2. Merancang keselarasan antara kebutuhan organisasi dan kemampuan pegawai

3. Menyediakan sarana, prasarana dan teknologi yang sesuai untuk pengembangan pegawai

4. Komitmen yang tinggi dari setiap elemen organisasi untuk melakukan pengembangan pegawai secara berkesinambungan.

Adapun desain pengembangan kompetensi SDM Bank Syariah dalam diskursus ini mengkombinasikan konsep yang dikemukakan oleh Spencer dalam self competence dan John W. Slocum tentang Organizational Competence yang keduanya saling berkontribusi dalam mencapai tujuan dari perbankan syariah dengan ditopang konsep Celestial Management oleh Riawan Amin.

Pertama, dalam konsep yang dikemukakan oleh Spencer bahwa kompetensi menunjukkan karakteristik yang mendasari perilaku yang menggambarkan motif, karakteristik pribadi (ciri khas), konsep diri, nilai-nilai, pengetahuan atau keahlian yang dibawa seseorang yang berkinerja unggul (superior performer) di tempat kerja. Ada 5 (lima) karakteristik yang membentuk kompetensi yakni 1). Faktor pengetahuan meliputi masalah teknis, administratif, proses kemanusiaan, dan sistem. 2). Keterampilan; merujuk pada kemampuan seseorang untuk melakukan suatu kegiatan. 3). Konsep diri dan nilai-nilai; merujuk pada sikap, nilai-nilai dan citra diri seseorang, seperti kepercayaan seseorang bahwa dia bisa berhasil dalam suatu situasi. 4). Karakteristik pribadi; merujuk pada karakteristik fisik dan konsistensi tanggapan terhadap situasi atau informasi, seperti pengendalian diri dan kemampuan untuk tetap tenang dibawah 
Suad Fikriawan. Manajemen Kompetensi Sumber Daya Manusia Bank Syariah ...

tekanan. 5). Motif; merupakan emosi, hasrat, kebutuhan psikologis atau dorongan-dorongan lain yang memicu tindakan.

Central and surface competencies

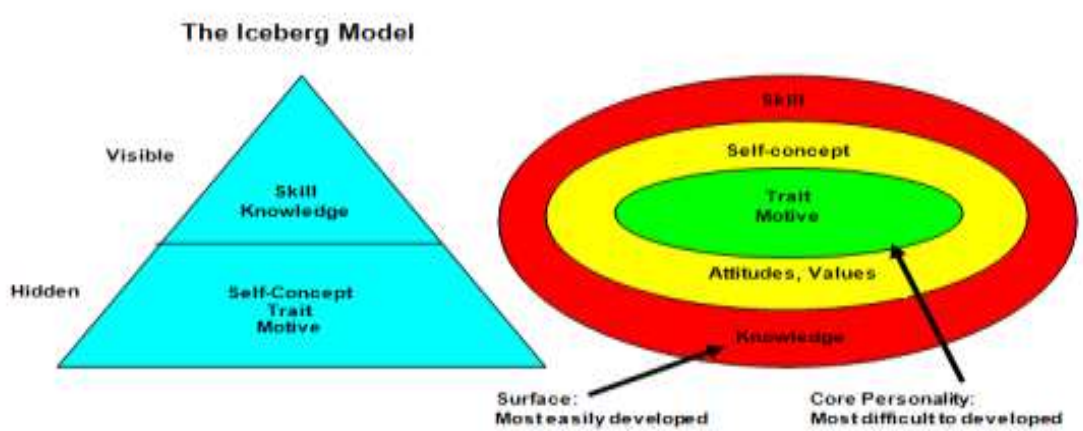

Sumber: Spencer, M., Lyle, Jr, \& Signe M. Spencer, Competence at Work "Models for Superior Performance", (New York: John Wiley \& Sons Inc, 1993)

Pernyataan di atas mengandung makna bahwa kompetensi adalah karakteristik seseorang yang berkaitan dengan kinerja efektif dan atau unggul dalam situasi pekerjaan tertentu. Kompetensi dikatakan sebagai karakteristik dasar (underlying characteristic) karena karakteristik individu merupakan bagian yang mendalam dan melekat pada kepribadian seseorang yang dapat dipergunakan untuk memprediksi berbagai situasi pekerjaan tertentu. Kemudian dikatakan berkaitan antara perilaku dan kinerja karena kompetensi menyebabkan atau dapat memprediksi perilaku dan kinerja. Adapun faktor pengetahuan dan keterampilan menjadi tolok ukur yang nyata dalam pengembangan kompetensi, sedangkan konsep diri, karakteristik pribadi, dan motif merupakan kompetensi yang tak tampak dan sulit diukur, namun keduanya saling berkaitan dengan pencapaian kinerja dalam organisasi.

Maka, dalam perbankan syariah khususnya desain pengembangan dan pembinaan karir yang meliputi aspek professional dan spiritual harus berhubungan satu sama lain dan saling menunjang melalui proses evaluasi pengembangan karir pegawai. Dengan demikian pencapaian hasil kompetensi pegawai secara komprehensif akan membantu pencapaian visi misi organisasi dengan baik. Konsep yang mendukung statemen tersebut adalah John W. Slocum yang menyatakan bahwa manajemen kompetensi pribadi yang komorehensif menjadi pondasi utama dalam mencapai serangkaian kompetensi lainnya secara efektif dalam lingkup organisasi. Slocum menawarkan enam kompetensi dasar yang menjamin efektifitas suatu organisasi. Gambarannya sebagai berikut:

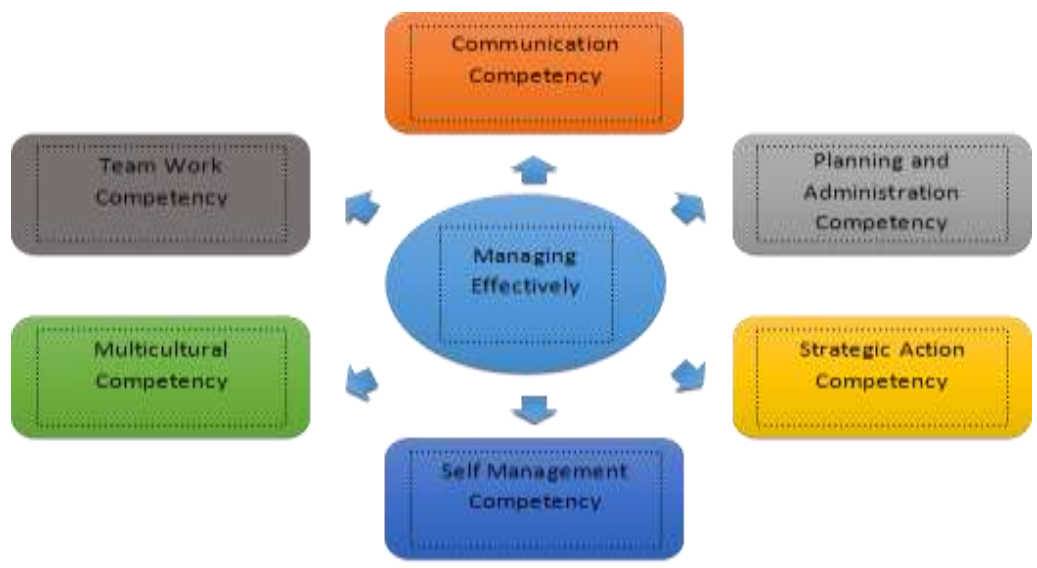

Sumber: John, W. Slocum, DKK, Competency-Based Management, USA, Thomson South Western, 2008 
Kedua konsep tersebut akan menjadi konsep manajemen kompetensi yang dapat dipraktikkan secara islami bila dilandai oleh nilai-nilai langit sebagai pendekatan spiritual dalam praktik bisnis yang menggunakan prinsip $3 \mathrm{~W}$, yakni Worship, Wealth, dan Warfare (Riawan Amin, 2006):

1) A place of Worship (tempat menyembah), artinya tempat bekerja atau bisnisharuslah dimaknai sebagai tempat ibadah. Bekerja adalah bukan untuk mengabdi kepada pimpinan, tetapi bekerja lebih dari itu yaitu mengabdi kepada Allah SWT. Dengan menyadari dan menghayati bahwa manusia adalah hamba Allah, maka sewajarnyalah setiap manusia mengabdikan dirinya kepada Allah, dengan mengikuti segala aturan-Nya dan menjauhi segala larangan-Nya.

Hal ini sesuai dengan Firman Allah yang berbunyi: "Dan Aku tidakmenciptakan jin dan manusia melainkan supaya mereka menyembah-Ku" (QS. Adz-Dzaariyaat 51:56). Selanjutnya, dikemukakan satu lagi firman Allah yang maksudnya adalah seperti berikut: "Wabai sekalian manusia!Sembablah Tuban kamu yang telah menciptakan kamu dan orang-orang yang terdahulu daripada kamu supaya kamu bertaqwa” (QS. Al-Baqarah:2:21). Rasulullah SAW juga telah bersabda yang artinya: "Orang yang mencaripenghidupan itu adalah kawan Tuban" (HR. Al-Bukhari).

Ada perbedaan ketika bekerja untuk kerja (mencari nafkah) dan bekerja untuk ibadah. Bekerja untuk kerja (hanya mencari nafkah) akan cenderung menghalalkan segala cara untuk memperoleh hasil yang sebanyak-banyaknya. Sedangkan bekerja untuk ibadah melihat hasil yang baik hanya diperoleh dengan niat, tujuan, dan cara yang baik, yaitu dengan niat, tujuan, dan cara-cara yang dibenarkan oleh Allah SWT. Kalau hal ini diikuti, maka kemungkinan hasil yang diperoleh tidak begitu banyak tetapi ada nilai berkah di dalamnya. Oleh sebab itu, nilai-nilai Worship diturunkan dalam konsep ZIKR yaitu Zero Base, Iman, Konsisten, Result Oriented.

Zero Base. artinya pekerjaan, usaha atau bisnis haruslah dimulai dari hati atau niat yang bersih, tulus, dan suci, sehingga menerima dengan lapang dada apa yang diberi, tidak pernah menawar-nawar terhadap pemberian. Bersih dari paradigma yaitu tidak terbelenggu oleh masa lalu, tidak selalu terpancang apa yang dikerjakan di masa lalu, tetapi apa yang dihadapi pada saat sekarang ini (Riawan Amin, 2006). Hal ini sejalan dengan Ary Ginanjar Agustin (2006) bahwa tahap awal untuk membangun kecerdasan emosi dan spiritual adalah melalui penjernihan emosi (zero mind process) diantaranya dengan menjauhkan diri dari prasangka. Hindari untuk selalu berprasangka buruk, dan usahakan untuk berprasangka baik. Iman, artinya suatu keyakinan akan kekuasaan Allah SWT, keyakinan akan janji-janji Allah SWT.

Zero base tidak akan ada artinya apabila tidak diisi dengan iman. Setelah dimulai dari hati yang bersih lalu dilakukan dengan penuh keyakinan, dan selalu optimis, maka pada akhirnya iman (penuh keyakinan) tersebut dapat menghilangkan rasa takut dan cemas. Penuh keyakinan dapat merubah sesuatu yang tak mungkin menjadi mungkin (impossible to be possible). Jadi dalam bekerja atau melakukan bisnis harus disertai dengan suatu keyakinan terhadap diri sendiri bahwa diri ini mampu mengatasi masalah, mampu meraih prestasi dan sebagainya, karena Allah SWT sudah berjanji dalam firmanfirmanNya.

Konsisten, maksudnya untuk sampai pada titik sasaran, zero base dan iman harus dijaga secara konsisten/harus istiqomah dan kaffah. Banyak orang bisa membuat rencana dengan baik, tetapi ketika mengimplementasikannya tidak konsisten dalam mengarahkan kepada suatu tujuan yang telah ditetapkan, akibatnya keselarasan yang diharapkan tidak muncul/tidak tercipta, justru yang muncul kebimbangan oleh berbagai tarikan dan motif yang berbeda. Agar selalu konsisten, diri ini perlu hati-hati dalam memfokuskan usaha 
Suad Fikriawan. Manajemen Kompetensi Sumber Daya Manusia Bank Syariah ...

atau bisnis demi tercapainya sasaran. Jadi dalam melakukan suatu pekerjaan atau bisnis harus selalu konsisten, baik dalam niat, motivasi maupun tujuan.

Result oriented, dapat diartikan bahwa dalam bekerja atau bisnis sebagai suatu perwujudan ibadah, maka harus mempunyai Result Oriented. Result Oriented yang dimaksud disini adalah Mardhatillah/ Willing Of God (keridhaan Allah SWT). Jadi tujuan bekerja atau bisnis bukan semata-mata untuk memperoleh materi, tahta, gengsi, popularitas, tetapi result oriented yang harus dimiliki adalah keridhaan Allah SWT (The Ultimate Result).

2) A Place of Wealth (tempat mensejahterakan), artinya tempat bekerja atau bisnisharuslah dijadikan sebagai pusat dari berkumpul dan dibaginya kesejahteraan dengan adil. Kesejahteraan yang seimbang antara material dan immaterial. Penyelesaian tugas akan tergantung pada banyak faktor. Pembagian tugas itu harus jelas, sehingga apapun yang berkaitan dengan kesuksesan/kelancaran bekerja harus dibagi/sharing dengan adil. Allah SWT berfirman "Sesunggubnya Allah menyuruh (kamu) berlakuadil dan berbuat kebajikan" (QS. An-Nahl 16:90). Selanjutnya RasulullahSAW bersabda "Sesunggubnya orang-orang yang berlaku adil di sisi Allablaksana berada di atas mimbar yang terbuat dari cahaya. Mereka itu orangorang yang berlaku adil dalam memberikan bukum kepada keluarga dan rakyat yang mereka kuasai (perintah)" (HR. Muslim). Sedangkan dalam manajemen ini ada 4 atribut utama, yang terangkum dalam akronim P I K R (Power, Information, Knowledge, dan Reward).

a) Power Sharing (Pembagian kekuasaan), Pembagian kekuasaan/pendelegasiaan kekuasaan dapat diartikan bahwa seorang individu tidak bisa sendirian dalam bekerja tetapi haruslah berkelompok, bersama-sama dengan pegawai/karyawan lainnya, duduk bersama dalam sebuah team. Sehingga bagus tidaknya pekerjaan team, tidak lagi ditentukan oleh keunggulan satu/dua orang saja, tetapi oleh kekompakan mereka dalam menjalankan fungsinya masing-masing. Jadi dalam lingkungan kerja, harus dipahami peran masing-masing dan sesuai dengan jabatan masing-masing. Setiap individu harus kembali merenung siapa dirinya, sebagai apa, tugas apa yang menjadi bagiannya. Bila sebagai pimpinan apakah sudah ada power sharing/pembagian kewenangan sehingga dalam pengambilan keputusan tidak bertele-tele harus sampai pada pucuk pimpinan. Bila sebagai penerima delegasi harus dilaksanakan dengan penuh tanggung jawab. Allah SWT berfirman "Tolong menolonglah kamu sekalian dalam kebaikan dan taqwa" (QS. Al-Maidah 5:2). Selanjutnya, Rasulullah SAW bersabda "Hendaknya tiap dua orang dalam satu keluarga, yang satu keluar dan yang lain menjaga keluarga-keluarganya yang ditinggal, niscaya pahalanya terbagi antara keduanya sama" (HR. Muslim).

b) Information Sharing (pembagin informasi) Dalam melaksanakan tugas sebagai penerima pendelegasian (power sharing), ditentukan oleh terbaginya informasinya yang diperoleh. Jika individu bertugas di unit terbawah tentunya banyak informasinya dari atas, maka baik tidaknya/lancar tidaknya pekerjaannya juga ditentukan oleh pembagian informasinya. Bila informasi yang disampaikan tidak lengkap tentu penyelesaian pekerjaan tidak sempurna. Umpamanya informasi tentang teori, style atau skill untuk menyelesaikan pekerjaan.

c) Knowledge Sharing (pembagian pengetahuan), Pembagian informasi yang diperlukan akan sia-sia bila tidak terjadi knowledge sharing (pembagian pengetahuan dan keterampilan), sehingga yang mengetahui teknik-teknik permainan hanya itu-itu saja, akibatnya sebagian pegawai/karyawan tidak cukup pengetahuan dalam melaksanakan tugas. Dalam kaitannya dengan tugas, tidak hanya pimpinan saja yang mendapat pengetahuan, tidak hanya yang mendapat pelatihan saja yang mengetahui ilmu-ilmu tertentu, tetapi harus dibagi kepada semua yang terkait, dengan cara ditularkan dan 
ditransfer kepada yang tidak mendapat pelatihan, atau yang tidak mempunyai pengetahuan.

d) Reward Sharing (pembagian hadiah/ganjaran). Setelah kekuasaan dibagi/didelegasian, informasi diperoleh, pengetahuan dan skill dikuasai, tinggal satu hal yang perlu diperoleh, yaitu naluri untuk menjadi pekerja atau karyawan yang sukses, seperti dalam permainan sepak bola naluri mencetak gol. Pemain akan berlomba-lomba mencetak gol bila ia cukup terangsang dengan imbalan yang akan diterima. Imbalan untuk pemain/pekerja itulah yang disebut Reward. Reward tidak selalu berbentuk uang, tetapi juga penghargaan, sekurang-kurangnya pengakuan dari atasan. Jadi reward diterima terakhir, setelah ada prestasi. Orang/pejabat yang mempunyai kekuasaan untuk memberikan reward harus memperhatikan prestasi pegawainya/bawahan sehingga reward betul-betul akan terbagi sesuai dengan presatasi masing-masing. Jadi prestasi dulu yang diwujudkan, baru ada reward, bukan sebaliknya reward dipersoalkan dulu, baru prestasi. Disamping reward positive ada juga reward negative. Sudah sewajarnya bila setiap prestasi mendapat apresiasi, demikian pula bila terjadi sebaliknya, manajemen seharusnya memberikan reward negative atau hukuman (punishment). Dalam pemberian punishment ada satu sikap yang menjadi pedoman. Kalau memang ditemukan kesalahan, sanksi harus dijatuhkan, tidak perlu kemudian diringan-ringankan dan ada pertimbangan pribadi sehingga keputusan menjadi tidak obyektif.

3) A Place of Warfare (tempat pertempuran), Misalnya dalam dunia penegakanhukum, peradilan harus mampu menjadi medan pertempuran dalam mewujudkan keadilan, bukanlah Islam hadir justru untuk menegakkan keadilan bukan untuk merobohkannya? Dalam dunia bisnis juga harus mampu menjadi medan pertempuran dalam memajukan ekonomi umat/rakyat. Untuk menjadi the dream team disegala medan pertempuran, setiap karyawan/pergawai harus membekali diri dengan atribut M I K R (Militan, Intelek, Kompetitif, Regeneratif).

a) Militan, Dalam pekerjaan atau bisnis, kita tentunya dihadapkan dengan pertempuran, persaingan/kompetisi dalam bekerja, kita akan memilih sesuatu untuk menjadi pemenang dalam persaingan. Pilihan yang sulit tidak mungkin lahir dari individu yang pengecut, bukan pribadi yang loyo, tetapi pribadi yang mempunyai semangat yang tinggi dan teguh pendirian dalam mengerjakanya, itulah yang disebut Militan. Militan artinya "bersemangat tinggi", 'penuh gairah' (kamus besar bahasa Indonesia). Dia siap untuk memberikan hasil yang baik serta semangat untuk berjuang, dan dia hadir untuk menjadi pemenang bukan pecundang. Kelompok militan mempunyai fungsi secara maksimal, mereka adalah pribadi yang pintar itu menggunakan pikirannya untuk mencari sebuah solusi dari problem-problem yang ada di samping mereka

b) Intelek, adalah kemampuan untuk menggunakan pikirannya dalam mencari sebuah solusi dari masalah-masalah yang ada. Orang intelek akan menggunakan semua knowledge dan skill yang membutuhkan untuk berprestasi. Ia akan memaksimalkan attitude positif untuk mendorong kebutuhan untuk memajukan diri dan lembaga tempatnya berkiprah. Allah SWT berfirman "Maka bertanyalah kepada orang yangmempunyai pengetahuan jika kamu tidak mengetabui" (QS. An-Nahl26:43). Selanjutnya, Rasulullah SAW bersabda "Dan apa yang akuperintabkan kepada kalian, maka laksanakan semampu kalian" (HR. Al-Bukhari dan Muslim). Kelompok intelektual yang dibuat di dalam fondasi yang militan akan melahirkan para pejuang yang siap untuk memberikan keterampilan yang terbaik. Dalam kata lain militan akan memberikan hasil atau kemampuan yang terbaik. 
Suad Fikriawan. Manajemen Kompetensi Sumber Daya Manusia Bank Syariah ...

c) Kompetitif, adalah mereka yang tidak saja memiliki penguasaan knowledge dan informasi yang dibutuhkan untuk berprestasi, tetapi juga mereka yang mempunyai kemauan untuk berperan serta menyumbangkan kinerja terbaiknya buat organisasinya. Allah SWT berfirman "Maka berlomba-lombalah kamu dalamberbuat kebaikan" (QS. Al-Baqarah 2:148, Al-Maidah 5:51). Selanjutnya,Rasulullah SAW bersabda "Seorang muslim yang menjadi bendabara,adalab orang yang dapat dipercaya. Ia melaksanakan tugas yang dilimpabkan dengan sempurna dan senang hati, serta memberikan sesuatu kepada siapa yang diperintabkan, maka ia termasuk salab sorang yang mendapat pahala bersedekah" (HR. Bukhari dan Muslim).

d) Regeneratif, artinya kemampuan kompetitif atau kesuksesan yang didapatkan dan harus bisa dijaga terus-menerus serta diwariskan kepada generasi berikutnya. Generasi yang cakap adalah generasi yang dilahirkan dan dibangun serta bisa membangkitkan pemimpin yang kompetitif yang mempunyai waktu yang panjang. Maksud dari kalimat di atas bahwa kesuksesan itu tidak hanya dicapai dalam satu periode, tetapi membutuhkan periode berikutnya/generasi penerus. Kunciya terletak pada kesadaran dan kesabaran dari setiap karyawan/pegawai untuk terus ZIKR dan Sharing PIKR. Allah SWT berfirman "Dan sesunggubnyaKami benar-benarakan menguji kamu agar Kami mengetabui orang-orang yang berjihad dan bersabar di antara kamu" (QS. Muhammad 47:31). Selanjutnya,Rasulullah SAW bersabda "Semua kebaikan yang ada padaku tidak akanaku sembunyikan pada kalian. Siapa saja yang menjaga kehormatan dirinya, maka Allab pun akan menjaganya dan siapa saja yang merasa cukup, maka Allab akan mencukupinya. Serta siapa saja yang menyabarkannya dirinya, maka Allah pun akan memberi kesabaran. Dan seseorang tidak akan mendapatkan anugerah yang lebib baik atau lebih lapang melebibi kesabaran" (HR. Bukhari dan Muslim).

Ketiga prinsip tersebut menjadi landasan universal dalam praktik bisnis. Bila dalam suatu organisasi dapat menerapkan ketiga prinsip diatas maka para pegawai atau karyawan disuatu perusahaan mampu bersaing secara global. Sebab universalitas nilai-nilai tersebut mampu beradaptasi pada setiap perubahan dan lingkungan bisnis yang ditempati pegawai. Karena dalam konteks global perubahan tidak melihat seberapa siap suatu organisasi merespon perubahan tersebut, jika respon suatu organisasi lambat dikarenakan regulasi yang tidak berbasis pada nilia universal maka akan tertinggal dari yang lainnya.

\section{c. Fungsionalisasi Nilai-Nilai Syariah Dalam Desain Manajemen Kompetensi SDM Bank Syariah}

Secara struktural, ujung tombak kemajuan perbankan syariah berada pada bank-bank yang beroperasi di tingkat cabang. Seberapa baik dan strategisnya kebijakan pusat, bila kemampuan beroperasinya tidak baik maka pencapaian target-target bisnis akan gagal. Maka dalam konteks ini pembinaan dan pengembangan mutu pendidikan dan kompetensi Bankir Syariah harus berlandaskan pada nilai-nilai syariah secara kompresehsif dengan muatan kompetensi teknis yang baik pula. Meskipun dalam proses pelatihan dilakukan secara berjenjang namun setiap komponen didalamnya harus mencakup beberapa aspek yaitu aspek personal (skill, knowledge, traith, values, and motive) maupun aspek organisasional (kompetensi komunikasi, perencanaan, strategi aksi, manajemen diri, kompetensi multicultural, dan team work). Dalam dua wilayah tersebut penanaman nilai-nilai syariah yang mencakup tiga prinsip dasar (Worship, Wealth, and warfare) harus ada dengan muatan materi yang proporsional dengan jenjang karir setiap pegawai bank syariah.

Misalnya pada program core trainingdi bank Syariah Mandiri. Jenis training ini diikuti oleh seluruh staff baru yang akan menempati berbagai posisi jabatan di Bank Syariah 
Mandiri. Training ini mencakup hal-hal yang mendasar seperti visi-misi, dan nilai dasar dari perusahaan. Maka dalam training ini materi yang disampaikan mampu mendesain paradigma pegawai baru yang akan bekerja di BSM. Jika konsep dasar visi misi dan nilai-nilai syariah tidak tersampaikan secara baik maka tujuan utama para staff bekerja di bank syariah mandiri tentu tidak sesuai dan sejalan dengan visi misi perusahaan. Maka jenis training ini sangat menentukan aras baru visi misi Bank Syariah di tangan para pegawai barunya. Kedua, ada funcional training yang bertujuan meningkatkan kompetensi teknis sesuai dengan jabatan pegawai. Dalam training ini kompetensi individual diharapkan mencakup berbagai aspek, tidak hanya teknis tetapi aspek non teknis seperti nilai diri dan motivasi yang berasaskan nilai-nilai syariah. Karena kebanyakan dari pesertanya memangku jabatan di front officer yang bekerja "monoton". Jika tidak dibekali aspek nilai dan motivasi yang tinggi maka pekerjaan mereka akan minim inovasi dan pelayanan yang prima.

Kemudian ada beberapa pelatihan yang bertujuan meningkatkan aspek behavior and managerial pegawai. Training ini diikuti oleh staff yang menduduki jabatan setingkat manajer dan staf diatas front officer. Pada aspek profesionalitas dan skill mereka sudah dianggap mumpuni, tetapi aspek spiritualitas terkadang diabaikan. Aspek ini menjadi penting karena mereka akan menjadi panutan dan teladan bagi staf dibawahnya. Aspek spiritualitas tidak hanya mampu mengasah insting bisnis dan skill on decision maker saja tetapi lebih dari ini mereka akan menderivasikan visi-misi perusahaan dalam setiap kebijakan teknis yang akan dilaksanakan oleh bawahannya. Bila setiap kebijakan kering spiritualitas maka preasure nya hanya target-target material saja. Dan pada akhirnya visi misi kesyariahnnya tidak pernah tercapai.

Sebaliknya, bila nilai-nilai syariah mampu mewarnai aspek spritualitas dalam kinerja yang terserap melaluitrainingnya, maka hipotesis yang dikemukakan Spencer bahwa spiritualitas akan berdampak signifikan pada target-target material menjadi signifikan. Dengan kata lain spiritualitas adalah kunci pokok dalam meningkatkan asset perbankan syariah. Seperti kita ketahui bahwa prasyarat utama qualified asean bank adalah tingkat asset yang tinggi sesuai ketentuan dalam ABIF. Maka bisa disimpulkan pula bahwa stagnasi perbankan syariah dari sisi asset dan permodalan bisa dikarenakan faktor spiritualitas dan nilai-nilia syariah yang terabaikan.

\section{PENUTUP}

Berdasarkan uraian pada setiap sub bahasan diatas dapat disimpulkan bahwa manajemen kompetensi SDM Bank Syariah perlu adanya pembenahan secara fundamental utamanya aspek nilia dan motivasi yang dibangun sejak awal bagi para pegawainya. Kemudian elemen-elemen penting yang terbentuk dalam idnivisu akan mempengaruhi efekifitas manajerial dalam perusahaan secara menyeluruh. Berdasarkan teori yang dikemukakan oleh Spencer dan John W. Slocum dalam Personal Competency dan Organizational Competency yang menyatakan bahwa ketika enam aspek yangmempengaruhi pribadiakan membentuk kmpetensi yang unggul bagi seorang pegawai, maka itu menjadi bagian penting yang membentuk enam kompetensi dalam organisasi. Dalam perspektif Islam tentunya kolaborasi antara dua teori tersebut relevan jika didasarkan pada 3 prinsip yaitu Worship, Wealth, dan Warfare dalam perusahaan.

Pada akhirnya jika aketiga gabungan konsep dan teorinitu berjalan secara baik akan membentuk kompetensi perusahaan yang efektif dalam mencapai tujuan perushaan utamanya dalam konteks Asean Economic Community perbankan syariah dituntut untuk mengembangkan asset dengan sedemikian rupa sehingga akan mampu bersaing dalam tingkai Global di Asean (Qualified Asean Bank) dengan standarisasi asset yang tinggi oleh ABIF. Dan hal ini mungkin bisa dicapai jika kompetensi Pegawai Bank Syariah unggul dalam bidang kerjannya dan unggul dalam nilainilai kesyariahannya. 
Suad Fikriawan. Manajemen Kompetensi Sumber Daya Manusia Bank Syariah ...

\section{DAFTAR PUSTAKA}

A.B Setiawan, Perbankan Syariab; Challenges dan Opportunity untuk Pengembangan di Indonesia. Jurnal Kordinat. Edisi: Vol.VIII No.1, 2006.

A.B Sulistiyo,.Memahami Konsep Kemanunggalan dalam Akuntansi: Kritik atas upaya Mendekonstruksi Akuntansi Konvensional menuju akuntansi syariah dalam bingkaiTasawuf. Jurnal Akuntansi Universitas Jember. 2010, Vol. 8 No. 1

Ahmad Azmy, Mengembangakan Human Resources Management yang Strategis untuk menunjang Daya Saing Organisasi; perspektif Manajemen kinerja di Bank Syariah, Binus Bussines Review, Vol 6 No. 1 Mei 2015

Bank Indonesia, Statistik Perbankan Indonesia, Vol: 13 No. 1, Desember 2014

Global Islamic Financial Report tabun 2015 Sumber: http://hdr.undp.org/en/composite/HDI

https://m.tempo.co/read/news/2015/11/22/087721104/ini-7-masalah-bank-syariah

Harian Tempo, Ini 7 Masalah Bank Syariah, diakses tanggal 11 Desember 2016

John, W. Slocum, DKK, Competency-Based Management, USA, Thomson South Western, 2008

Laporan Tahunan Bank Indonesia Tahun 2012

Muhammad. Manajemen Bank Syari'ah. Yogyakarta: UPP AMP YKPN, 2005

Muhammad. Pengantar Akuntansi Syariah. Salemba Empat. Jakarta; Salemba Empat (2005)

Nurhayati, S. Dan Wasilah. Akuntansi Syariah di Indonesia, Edisi 2. Penerbit Salemba Empat. Jakarta. (2009)

Rukiah, Strategi Pengembangan SDM Syariah menghadapi Pasar Global, At-Tijarah Volume 1, No. 2, Juli-Desember 2015

R. Palan, Competency Management a Practitioner's Guide, Malaysia; Specialist Management Resources Rosetta Solution, 2003

Siaran Pers NO.SP-58/DKNS/OJK/12/2014, 13 Desember 2014

Surya Dharma, Paradigma Baru: Manajemen Sumber Daya Manusia, Yogyakarta, Amara Books, 2007

Spencer, M., Lyle, Jr, \& Signe M. Spencer, Competence at Work "Models for Superior Performance", (New York: John Wiley \& Sons Inc, 1993) 